\title{
The Prospects of Uganda's Iron Ore Deposits in Developing the Iron and Steel Industry
}

\author{
Muwanguzi J. B. Abraham 1*, Rukezo Gift², Sebukeera Hennery¹, Guloba Asuman'1, Ajidiru Rita1, \\ Dumba Dexter ${ }^{2}$, Muvawala Joseph ${ }^{1}$
}

\author{
${ }^{1}$ Science, Technology and Innovations Department, National Planning Authority, Kampala, Uganda \\ ${ }^{2}$ Transport \& Infrastructure Expertise Group Ezhz (Tieg), Stupava, Slovak Republic \\ Email: *abraham.muwanguzi@npa.go.ug, ${ }^{*}$ ajbm@kth.se
}

How to cite this paper: Abraham, M.J.B., Gift, R., Hennery, S., Asuman, G., Rita, A., Dexter, D. and Joseph, M. (2020) The Prospects of Uganda's Iron Ore Deposits in Developing the Iron and Steel Industry. Journal of Minerals and Materials Characterization and Engineering, 8, 316-329.

https://doi.org/10.4236/jmmce.2020.84019

Received: May 25, 2020

Accepted: July 27, 2020

Published: July 30, 2020

Copyright $\odot 2020$ by author(s) and Scientific Research Publishing Inc. This work is licensed under the Creative Commons Attribution International License (CC BY 4.0)

http://creativecommons.org/licenses/by/4.0/

\begin{abstract}
Uganda aspires to exploit its abundant iron ore resources to supply the required raw material for developing its iron and steel industry across all the phases of the value chain. The country imports USD 369 million worth of iron and steel products annually, $60 \%$ of which are raw materials for the steel processing plants. The National Planning Authority, the government planning agency, undertook a study to assess the possibility of using the iron ore deposits available in the country, as a source of supply for iron and steel production. In the study, available geological literature was collected from various sources and analysed in order to understand the mode of iron ore mineralization in Uganda, particularly, that in the South West. A field excursion to the deposits was conducted in order to ground truth the information obtained from literature research; carry out a detailed reconnaissance study so as to benchmark the likely scenarios required in the development of the iron and steel value chain; and establish the likely mining and processing requirements of the deposits. The reconnaissance survey confirmed the existence of hematite deposits that visually show characteristics of high-quality iron ore $(55 \%-68 \% \mathrm{Fe})$ suitable for iron production. From surficial investigations, the deposits are mainly comprised of thin beds of mineralisation. The deposits occur in the form of massive hematite, which is amenable to mining and direct feed to the ore processing plants, and specularite hematite (a metamorphic platy variety), which normally requires mineral processing for amenability to reduction processes. From the analysis, the country has sufficient deposits of a high grade that can support a steel industry, though more detailed quantifications and characterisations need to be prioritised by the government.
\end{abstract}

\section{Keywords}

Mineralization, Iron Ore, Iron, Steel, Geology, NPA, Uganda 


\section{Introduction}

Uganda aspires to become an upper middle income country by the year 2040 and the national planning frameworks [1] [2] [3] have earmarked the development of the country's iron and steel industry, based on the existing natural iron ore resources, among the key interventions to be used to achieve the desired vision. In order to guide investments towards developing the industry, the country banned the exportation of unprocessed iron ore in 2011, so as to promote value addition in the iron and steel sector. Despite having huge deposits of iron ore, the country's trade deficit in iron and steel products was standing at about USD 200 million by end of 2018 [4] and lacks any iron ore smelting plant. According to data from the Directorate of Geological Survey and Mines (DGSM), the country's iron ore resources are estimated to be about 580 million tonnes, Table 1 and they majorly exist in the southwestern and eastern part of the country, Figure 1.

The iron ore deposits in southwestern Uganda are among the best grades in the world [5] [6]. A study was conducted to analyse the possibilities of exploiting these deposits for the development of the country's iron and steel industry to meet national and regional iron and steel demands.

Uganda has a geological history spanning a number of years. It is part of the Congo-Tanzania Craton, lying on the north-eastern part, comprising of Archaean lithospheric fragments which are intersected or surrounded by Proterozoic fold belts related to a series of orogenic cycles including the Eburnian (2.20 - $1.85 \mathrm{Ga})$, Grenvillean (1.10 - $0.95 \mathrm{Ga}$ ) and Pan-African (0.75 - $0.50 \mathrm{Ga}$ ) orogenic cycles [7] [8] [9] [10]. Post Pan-African orogenic cycles are sedimentary suites of the Karoo and the Neogene East Africa Rift System comprising mainly of Molasse assemblages including shales, sandstones and conglomerates.

The iron ore deposits of Uganda fall into two systems, the Karagwe-Ankolean

Table 1. Known iron ore mineral resource in Uganda.

\begin{tabular}{ccccc}
\hline Type of iron ore & Location & $\begin{array}{c}\text { Region in } \\
\text { Uganda }\end{array}$ & $\begin{array}{c}\text { Quantity } \\
\text { (million tonnes) }\end{array}$ & $\begin{array}{c}\text { Fe Content } \\
(\%)\end{array}$ \\
\hline Haematite $\left(\mathrm{Fe}_{2} \mathrm{O}_{3}\right)$ & Buhara & & 205 & 68 \\
& Rubuguri & & 55 & 69 \\
& Rugando & South & 65 & 67 \\
& Muko & Western & 155 & 68 \\
& Mugabuzi Hill & & 12 & 60 \\
Magnetite $\left(\mathrm{Fe}_{3} \mathrm{O}_{4}\right)$ & Nyaituma & & 5 & 60 \\
& Bakusu, Nakhupa, & & 41 & 50 \\
& Nangawale, Surumbusa & Eastern & 45 & 60 \\
TOTAL & Tororo & Uganda & 45 & 65.87 \\
\hline
\end{tabular}

Source: Directorate of Geological Survey and Mines, 2018. 


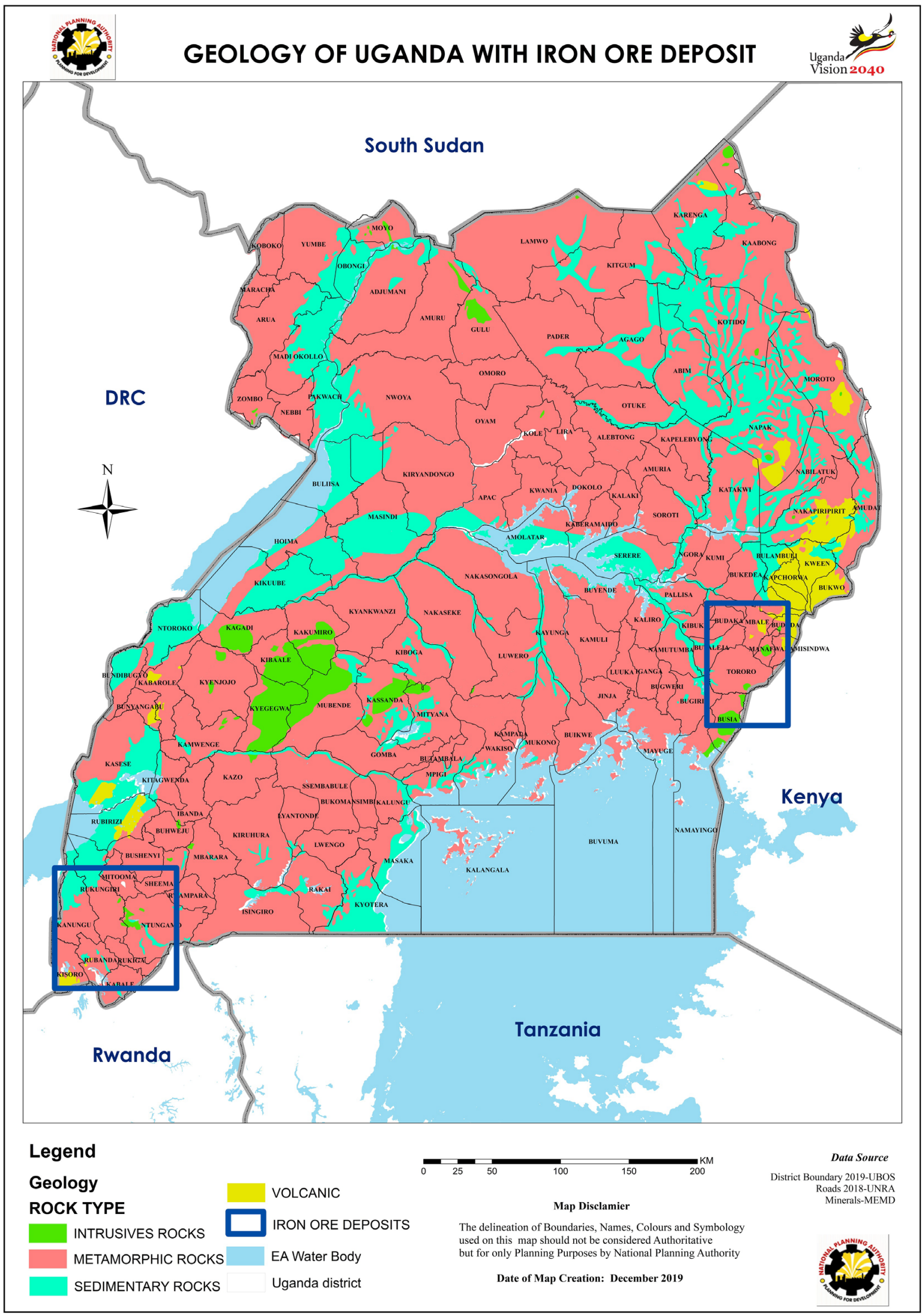

Figure 1. Locations of iron ore deposits in Uganda (Source-National Planning Authority). 
system (1.8 - $2 \mathrm{Ga})$ hosting the hematite deposits of South Western Uganda and the Alkaline/Carbonatite complexes of the Cenozoic period ( $40 \mathrm{Ma}$ ) hosting magnetite deposits of Eastern Uganda [11] [12] [13].

Between the two ironstone deposits, the hematite ores of South Western Uganda are considered more prospective with potential for huge discoveries. They are also of a superior grade with most of the samples collected in the area posting iron content ranging from $55 \%$ to $68 \% \mathrm{Fe}$ as opposed to magnetite deposits of Eastern Uganda with iron content of $40 \%$ to $62 \% \mathrm{Fe}$, as is highlighted in Table 1 and later in this paper. For this reason, the iron ore deposits of South Western Uganda are considered as the preferred source of raw material for the proposed integrated iron and steel value chain development.

The iron ore deposits are comprised of a series of hematite beds interbedded conformably with metamorphosed sedimentary horizons of pink/grey phyllites that are believed to be of mudstone, shale and sandy origin, which points towards a sedimentary source of the deposits. Banding and vuggy quartz have been observed on the Kihimuro outcrops (Figure 2) suggesting a Banded Iron Formation (BIF) type deposit. The deposit is comprised of a series of thin beds ranging from $5 \mathrm{~m}$ to about $100 \mathrm{~m}$ wide, with a general Northwest-Southeast (NW-SE) strike direction and dipping at $30^{\circ} \mathrm{SW}$ to almost vertical.

\section{Methodology}

The paper was prepared based on both desk and field research. Available geological literature was collected from various sources, mainly from the Directorate of the Geological Survey and Mines (DGSM) based in Entebbe, Uganda and analysed in order to understand the mode of iron ore mineralization in Uganda-in particular, iron ore deposits of South Western Uganda.

A field excursion to the iron ore deposits of South Western Uganda was conducted in order to ground truth the information obtained from literature research; carry out a detailed reconnaissance study so as to benchmark the likely scenarios required in the development of the value chain; and to establish the likely mining and processing requirements of the deposits. As part of the excursion, the land surrounding the ore deposits was assessed for suitability for infrastructure development and logistics taking into consideration the environment and social issues.

\section{South Western Iron Ore Deposits}

Iron ore deposits occur in Kisoro and Kabale districts, in the hills in the southwestern part of Uganda. The deposits can be found on the hills of Kamena, Nyamiyaga, Kyanyamuzinda, Rushekye, Butare, Kashenyi, among others, Figure 1 and Figure 2. From Kampala, the capital city of Uganda, the area can be accessed by taking the Kampala-Masaka-Mbarara road to Kabale town, a distance of $430 \mathrm{~km}$ on a tarmac road. From Kabale, the deposits are accessed by following the Kabale-Kisoro road, for a distance of $48 \mathrm{~km}$ to a town called Mukatojo. 


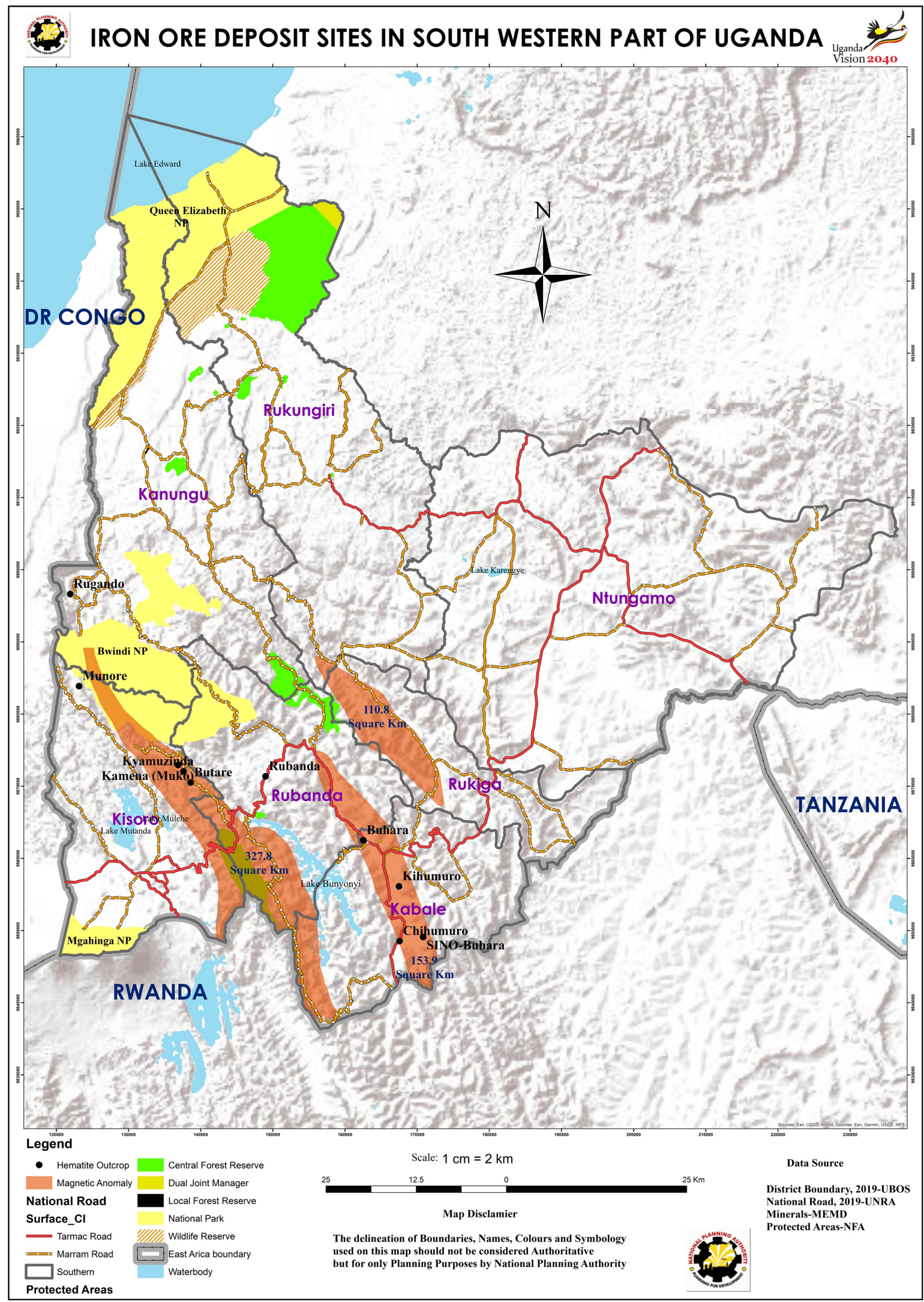

Figure 2. Geophysical map overlain with outcrops mapped in South West Uganda (Source-National Planning Authority). 
Turning to the right, all the hills can be accessed at a distance of about $3 \mathrm{~km}$.

The deposits are located in a mountainous area and the ore is embedded within rocks that form this mountainous terrain. The deposits contain rich grades of hematite which presents a potential opportunity for Uganda's industrial development and a big input to the world's iron and steel market.

\subsection{Geology of the Deposit Area}

Generally, the area is underlain by weakly metamorphosed sequence of argillic and arenaceous rocks of Kibaran System (Karagwe-Ankole rocks) [11]. The argillic rocks consist of mustones, shales and phyllites while siltstones, sandstones, quartzites and arkoses make up the arenaceous group. The phyllites show a foliation and the commonest type of phyllites is the grey, sandy variety, which weathers to a very fine-grained silty clay, and the second variety weathers to plastic finely banded red, yellow and grey clay [11] [14]. The ironstone also occurs as outcrops and floats and shows a metallic grey luster. The phyllites, which exist as intercalations with ironstones are grey in colour.

\subsection{Mineralisation of the South Western Iron Ore Deposits}

Mineralisation is mainly hematite which is usually metallic grey in colour and highly foliated attaining the specular texture [14]. Like the enclosing country rocks, the hematite horizons are also marked by steep angles of dip. Occasionally, fine to medium grain octahedral magnetic crystals are found mixed with hematite.

The deposits pose conflicting views about the origin (genesis) of the ore bodies. Sekamwa [15] considers the iron ore to be of sedimentary origin with late metamorphism while Barnes [16] and Clark [11], considered them to be products of replacement of shales [11] [15] [16]. The broad conformable nature of the ore lenses with the bedding (lithological layering) of the enclosing rocks on the regional scale lends credence to the sedimentary origin of the ore. Metamorphism and local remobilisation is manifested by the development of specularite and crosscutting quartzite veins [11]. It is suggested that colloidal silica and ferric hydroxide were mixed in the sediments when they were laid down, and during metamorphism they were subsequently recrystallised.

From field evidence, Clark suggested that hematite deposits in the region of Kashenyi are of the replacement type. Hematite bodies are hosted by phyllites. Byamugisha noted that the iron ore mineralisation is enclosed within steeply dipping phyllites [17]. Baguma observed that the iron ore mineralisation is found interbedded within the metasedimentary sequences of the KaragweAnkolean rocks [18].

In its primary state, iron exists in the form of silicates, sulphides and carbonates. During weathering in the presence of water and oxygen, decomposition takes place by oxidation and hydrolysis and subsequent reduction to iron occurs under various conditions. Precipitation, dissolution and reprecipitation of the 
various Fe oxides in the environment depend predominantly on factors such as $\mathrm{pH}, \mathrm{Eh}$, temperature and water activity [19]. For this reason, existence of different Fe oxides may serve as an indicator of the type of environment that prevailed during their formation.

Understanding the layout of the region will ease the work of exploitation of the ore during exploration and mining. Generally, the iron ore is predominantly hematite. The ore is found embedded in rocks that make-up the terrain of the region, with the phyllites occupying a greater area than the quartzites. The quartzites are hard to break but their occurrence in medium grained flinty rocks makes the ore extraction much easier.

\subsection{Previous Works on the Deposits}

South-western Uganda was subjected to reconnaissance geological survey as early as 1920s when Uganda Geological Survey mapped the area under its regional geological mapping programme [20]. Much of the pioneering work in the 1920s was done by A.D. Combe who in 1943 reported exceptionally pure hematite float material and some limonite bands to occur in the famous Muko area, which he says are formed from the oxides leached from the shales and phyllites [21]. Combe had also made an investigation of the Butare iron deposits that he first recorded in January 1926 while making a reconnaissance traverse in Southern Kigezi. He reported exceptionally pure hematite float material to occur in the area.

In 1961, J.W. Barnes carried out a detailed investigation of the mineral resources of Uganda and reported remarkable pure iron ore, that according to chemical analyses, contained between 90 to 98 percent $\mathrm{Fe}_{2} \mathrm{O}_{3}$ with negligible phosphorous and sulphur whilst $\mathrm{TiO}_{2}$ only occasionally approaches $0.05 \%$ [16]. He estimated 30 million tonnes of ore from surface.

Clark carried out pitting at Kyanyamuzinda and delineated magnetic areas that corresponded with areas already marked by geological mapping [11]. In 1978, J. Sekamwa and Jombwe, sunk 17 drill holes in grid at Kyanyamuzinda in an area of $0.01 \mathrm{~km}^{2} .2 .37$ million tonnes of reserve where proven, averaging $64 \%$ $\mathrm{FeO}$ or $43.8 \% \mathrm{Fe}[22]$.

In 1963, Clark carried out preliminary prospecting of the iron occurrences at Kashenyi, Kyanyamuzinda and Kamena north, which involved mapping, pitting and trenching. Pits and trenches were limited to $6 \mathrm{~m}$ in depth. He found out that the quantity of the deposit was not as high as previously believed by J.W. Barnes. The laboratory analysis of samples collected during this programme was done by Almond, and revealed significant quantities of phosphorus and sulphur as compared to J.W. Barnes results [23]. The results obtained were; $80 \% \mathrm{Fe}_{2} \mathrm{O}_{3}, 6 \% \mathrm{SiO}$, $4 \% \mathrm{Al}_{2} \mathrm{O}_{3}, 0.35 \% \mathrm{P}_{2} \mathrm{O}_{5},<0.2 \% \mathrm{~S}$ and $0.2 \% \mathrm{TiO}_{2}$.

Between 1989 and 1996, subsequent surveys and studies were conducted in the area including trials for direct reduction of the ore [14] [24] [25] [26]. Most of these surveys where spearheaded by the Directorate of Geological Survey and 
Mines of Uganda and where conducted on individual hills or throughout the whole area. On average, about 30 - 50 million tonnes of reserves were estimated to occur in the area and the ore was found to exist as a rich hematite grade.

Between 2006 and 2013, Muwanguzi et al., [5] [6] [27] [28] [29] carried out investigation on iron ore samples collected from six hills namely; Rushekye, Kyanyamuzinda, Butare, Kashenyi, Nyamiyaga and Kamena. The investigations involved laboratory analysis of the physical, chemical and metallurgical properties of the ore to establish its suitability for iron and steel production, especially as a direct feed to the blast furnace. It was discovered that the iron ore is among the highest-grade deposits in the world, and it's physical, chemical and metallurgical properties allow it to be used as a direct feed to the blast furnace without further beneficiation into sinters or pellets. Specifically, as observed by Clark, the samples from Kashenyi had low $\mathrm{Fe}_{2} \mathrm{O}_{3}$ content, $86.7 \%$ and high contents of $\mathrm{SiO}$, $\mathrm{Al}_{2} \mathrm{O}_{3}, \mathrm{P}_{2} \mathrm{O}_{5}$, and $\mathrm{S}$ at $5.1 \%, 6.0 \%, 0.02$ and 0.003 respectively. The rest of the samples had high hematite content, $96.6 \%-98.7 \%$, and law quantities of inclusions as observed by earlier studies. Direct reduction simulations of the ore reduction also indicated that the ore can easily be used in the production of directly reduced iron (DRI).

From this background, it can be observed that a number of geological investigations have been carried out on the country's iron ore deposits, especially those in the southwestern part. It can be noted though that most of these investigations have been isolated, performed at small scales in relation to the extent of the deposit areas, carried out at considerably different times and do not give a conclusive picture of the ores' geometry and mineralisation, so as to inform its development. However, the available information can be very useful in informing planning procedures for the ore's exploitation and thus its analysis and collage are very important. This study therefore, assesses the extent to which the available information on the iron ore deposits compares with the ground data and the extent to which it can be relied upon to plan for the development of the iron and steel industry in the country. It further notes the gaps that need to be addressed along the way.

\section{Discussions}

During this study, it was discovered that geophysical survey conducted prior to this mission (as cited in the previous section) demonstrated similar strike trends to the observed structures in the field. Mapped outcrops coincide well with the geophysical anomaly, an indication of the authenticity of the geophysical signature mapping.

The geophysical mapping also conforms with the NW-SE strike trends of the hematite beds mapped during the reconnaissance survey. It can therefore be inferred that the strike extent of the geophysical anomaly depicts the lateral extent of the hematite deposits. The widths of the geophysical anomaly may not depict the thickness of the mineralisation considering that magnetic anomalies can be 
picked from iron dispersion due to weathering and other geomorphological processes that took place post the deposition of the iron oxides. This is where exploration mapping becomes important to ascertain the true geometry of the iron ore mineralisation and therefore an estimate of the quantities of ore available on the ground. Furthermore, expert analysis of the geophysical data can provide indications of thickness and minimum depth of the mineralisation expected on the deposit.

Faulting and zones of breccia were observed in the hematite outcrops, an affirmation of the literature that the deposits were subjected to intense structural deformation through folding and faulting, which probably occurred during the uplift and thrusting during the Eburnian orogenic cycle. Faulting probably explains the discontinuities and disappearances of the hematite beds from surface. The parallel hematite beds with striking similarity could probably have been continuous beds of ironstone that were thrusted, folded and uplifted, a process that could have triggered surface processes of weathering and erosion to remain with remnant parallel discontinuous lenses of the deposit.

Mineralisation is said to be more concentrated at the hinges of the folds' "anticlines (and possibly synclines)" depicting post thrusting (re)mobilization of the iron to form the deposits.

Texture of the hematite mineralization ranges from massive to foliated, with most of the foliated hematite being specularite with strong metallic lustre. The platy specularite has silica in-between indicating that the deposit could be a metamorphosed BIF. Vuggy quartz in the silica bands is a clear indication of hydrothermal enrichment of the iron within the deposit, which probably pre-dates the metamorphic process which produced specularite hematite schist, a variety of hematite characterized by aggregates of silvery, metallic, specular ("mirror-like") hematite flakes (Figure 3).

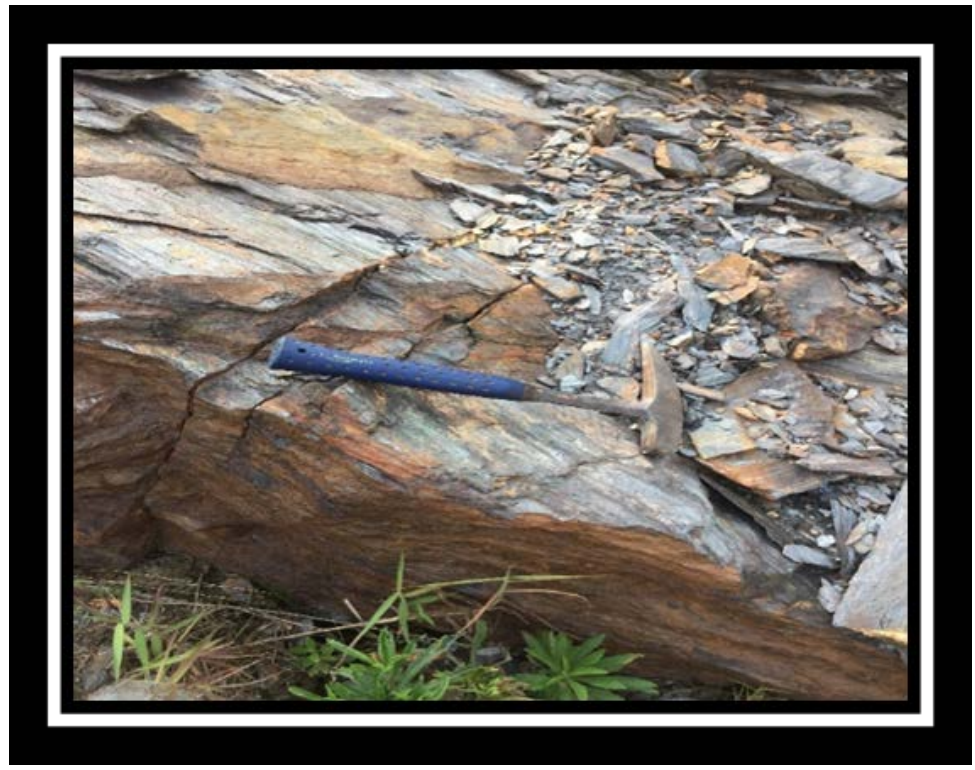

Figure 3. Specularite Hematite (Rugando Hill). 


\subsection{Geo-Metallurgical Properties of the Hematite Deposits}

Texture and structure of the hematite as described above has significant bearing on metallurgical processes of iron making. Whereas massive hematite is likely to produce lamp ore, which can be fed directly into iron making processes, the probability of high fines ore content, which would require pelletization or sintering for it to be amenable to iron making processes cannot be ignored. On the other hand, friable and flaky specularite may require processing (milling) especially in DRI processes, with subsequent requirement for sintering or pelletization after milling for amenability to iron making processes as the platy flakes may not support enough aeration for the flow of reductants. Evidence of these hematite properties are clear from the crushed and screened ore stockpiles on sites of the small-scale miners operating in the region. The massive hematite is likely to spit out high run-off-mine lump ore content on crushing and screening than the specularite ore, implying that if economic deposit(s) of lump ore are available, they are likely to be mined at lower cost considering they do not require further processing after mining and crushing, which, unlike fine ores or specularite, can be fed directly into iron making processes without the need for processing, sintering or pelletisation.

\subsection{Geological Resource/Reserve}

Several companies with operations, either exploration or mining, on the iron ore deposits in the country have come up with mineral resource figures which have been used to determine the total known iron ore resource in the country, as given in Table 1, including results of the mapping undertaken by DGSM. It is however emphasised that from the information in the available literature, and the reconnaissance mapping undertaken by the team on the ground, the resource figures quoted are crude estimates. There are no known reporting standards followed in defining the resource as is normally required in the profession of mineral exploration and ore evaluation. Only one company, with a 30 million tonne resource that remained open ended at depth, is the only company to have carried out reasonable exploration, with results that can be used to define a $3 \mathrm{D}$ geometry of the deposit in its license area. As such, caution should be taken when using these figures for the purposes of planning the development of the iron and steel industry. The resource therefore, has to be classified as inferred mineral resource, which emphasizes the need for further exploration to fully define the resource if meaningful planning for the development of the iron and steel value chain is to take place.

Based on the reconnaissance survey carried out in southwestern Uganda, it is obvious that high quality hematite deposits exist in the area, and with proper exploration, the potential for a measured mineral resource that is more than double the $583 \mathrm{Mt}$ in Table 1 can be a reality. A full exploration program for the entire deposit in the southwest should be a priority for the government if it is to unlock the value hidden in these iron deposits. It would be prudent for the gov- 
ernment to consider the development process as a national agenda whereby government investment into developing these resources can create accretive growth to the government asset base. Value of that investment can always be clawed back in several ways including PPP, JVs or through tender, with a benchmark price that reflects the amount of investment the government committed during the mineral resource development stage.

\section{Conclusions and Recommendations}

High grade hematite ore exists in South Western Uganda with known grades ranging from $55 \%$ to $68 \% \mathrm{Fe}$. These are typical grades required for production of quality iron for the subsequent production of quality steel products. The reserves indicated, if confirmed, are enough to support an iron and steel production value chain in the country. Additionally, the fact that the ore is outcropping points to the possibility of open pit mining method as opposed to the more costly underground mining, making the capital investment more affordable for the country. However, more needs to be done to enable the country fully benefit from these resources.

1) Analysis of the available literature does not show evidence that internationally recognised procedure for ore quantification was followed in order to arrive at the reported iron ore reserves. The government is encouraged to consider the exploration of the deposits as a national agenda and therefore invest to fully evaluate the deposits and delineate a mineral resource that can be used to plan the path the iron and steel value chain development should take. Exploration should be carried out by a professional organisation that can produce results that conform to the ongoing international reporting standards like the NI43-101 of Canada or the JORC code of Australia. There is significant value addition that is gained by using these standards especially when seeking investment from private/listed corporations, be it PPP, JVs or open tender.

2) Geological mapping of the entire ironstone region is highly recommended as a first step ahead of any other exploration activity in order to fully understand the extent and structural controls of the mineralization. Geological mapping and the geophysical survey information available will then pave the way for targeting and subsequent exploration strategy.

3) The available geophysical data should be further analysed by an expert geophysicist who can provide leads on the likely geometry and the minimum expected down-dip extension of the deposit. This data can provide information on the minimum required exploration activity in the early stages of the program.

4) The different hematite types (massive and friable specularite) should be sampled for metallurgical tests in the early stages of development of the iron and steel value chain. The results will inform the stakeholders on the likely scenarios required to prepare the ore for the reduction processes-Hematite fines from mining activity and the platy specularite ores may require sintering or pelletisation before feeding into the iron reducing processes. 
5) The numerous small-scale miners that have taken a position in the area, with either exploration or mining licenses issued to them, are a potential hindrance to large scale mining investment unless the government re-aligns its policies on the criteria for investment in bulk commodities like iron ore.

\section{Acknowledgements}

This work was funded by the European Union under a project titled, "Technical Assistance to the National Planning Authority, including a Feasibility Study for Establishing a Comprehensive Iron and Steel Industry in Uganda (Specific Contract Nr. 2019/406-879)".

\section{Conflicts of Interest}

The authors declare no conflicts of interest regarding the publication of this paper.

\section{References}

[1] National Planning Authority (2013) Uganda Vision 2040. National Planning Authority, Kampala.

[2] National Planning Authority (2010) National Development Plan (2010/11-2014/15). National Planning Authority, Kampala.

[3] National Planning Authority (2015) Second National Development Plan (NDPII) 2015/16-2019/20. National Planning Authority, Kampala.

[4] Uganda National Bureau of Statistics (2019) Statistical Abstract: Import/Export Statistics. Uganda National Bureau of Statistics, Kampala.

[5] Muwanguzi, J.B.A., Karasev, V.A. and Byaruhanga, K.J.P.G.J. (2012) Characterization of Chemical Composition and Microstructure of Natural Iron Ore from Muko Deposits. ISRN Materials Science, 2012, Article ID: 174803. https://doi.org/10.5402/2012/174803

[6] Muwanguzi, J.B.A., Karasev, V.A., Byaruhanga, K.J. and Pär, G.J. (2012) Characterisation of the Physical and Metallurgical Properties of Natural Iron Ore for Iron Production. ISRN Materials Science, 2012, Article ID: 147420.

https://doi.org/10.5402/2012/147420

[7] Phil, W.A.B., Paavo, H., Edward, I., Edwards, K., Tapio, K., Eira, K., Tapio, L., Matti, L.I.H.M., Tuomo, M., Irmeli, M., Yrjö, P., Jussi, P., Kerstin, S. and Petri, V. (2014) Geological Survey of Finland-Special Paper 55: Geology and Geodynamic Development of Uganda with Explanation of the 1:1,000,000 Scale Geological Map. GTK, Espoo, 2-14.

[8] Sandra, S. (2019) Paleogeographic and Tectonic Evolution of the Western Branch of the East African Rift System Using Multiple Provenance Methods (Albertine Rift, Uganda). Technische Universitat Darmstadt, Darmstadt.

[9] Block, S., Ganne, J., Baratoux, L., Armin, Z., Luis, P.-A., Jessell, M., Ailleres, L. and Siebenaller, L. (2015) Petrological and Geochronological Constraints on Lower Crust Exhumation during Paleoproterozoic (Eburnean) Orogeny, NW Ghana, West African Craton. Journal of Metamorphic Geology, 33, 463-494. https://doi.org/10.1111/jmg.12129

[10] Mahaman, S.T., Pascal, A., Solomon, A. and Thomas, J.F. (2012) Pan-African Pa- 
leostresses and Reactivation of the Eburnean Basement Complex in Southeast Ghana (West Africa). Journal of Geological Research, 2012, Article ID: 938927. https://doi.org/10.1155/2012/938927

[11] Clark, D.A.C. (1963) A Preliminary Report on Some Iron Ore Deposits at Kashenyi Ridge, near Muko, Kigezi District. Geological Survey and Mines Departent, Entebbe.

[12] Robin, N. (1965) The Structure and Metamorphism of the Mantling KaragweAnkolean Sediments of the Ntungamo Gneiss Dome and Their Time-Relation to the Development of the Dome. Quarterly Journal of Geological Society, 121, 143-156. https://doi.org/10.1144/gsigs.121.1.0143

[13] Wayland, E.J. (1933) Karagwe-Ankolean Rocks as a Repository for Gold. International Weekly Journal of Science, 132, 3330. https://doi.org/10.1038/132318c0

[14] Katto, E. (1997) Butare Iron Ore Prospects Muko Area, Kabale District Southern Uganda. Geological Survey and Mines Department, Entebbe.

[15] Sekamwa, J. (1974) Review of Iron Ore Occurrences in Uganda and Their Prospection and Exploration. Geological Survey and Mines Department, Entebbe.

[16] Barnes, J.W. (1961) The Mineral Resources of Uganda. Geological Survey and Mines Department, Entebbe.

[17] Byamugisha, S.S. (1988) A Review of the State of Exploration Activities on the Kashenyi Ridge under Muko Iron Ore Project. Geological Survey and Mines Department, Entebbe.

[18] Baguma, Z. (1989) Proposed Pitting, Trenching and YKB-12 YKB/25 Drilling Programme in Kashenyi. Geological Survey and Mines Department, Entebbe.

[19] Schwertmann, U. and Cornell, R.M. (2008) Iron Oxides in the Laboratory: Preparation and Characterisation. 2nd Edition, Wiley-VCH, New York, 15.

[20] Celenk, O., Byamugisha, S.S., Baguma, Z., Katto, E., Ongom, W., Brohan, M., Tuhumwire, J. and Waluganja, A. (1993) Iron Ore Potential of Muko Area (Kashenyi, Kamena and Butare), SW Uganda. Geological Survey and Mines Department, Entebbe.

[21] Combe, A.D. (1942) The Butare Iron Deposit, Southern Kigezi, Southwestern Uganda. Geological Survey and Mines Department, Entebbe.

[22] Sekamwa, J. and Jombwe, N. (1997) Progres Report on the Geological Exploration Activities at Kashenyi Ridge Iron Ore Deposit. Geological Survey and Mines Department, Entebbe.

[23] Almond, J.A. (1964) Economic Prospects of High-Grade Hematite Deposits near the Muko Southwest Kigezi. Geological Survey and Mines Department, Entebbe.

[24] Enrico, M. (1992) Project Technical Assistance Strengthening DSGM in the Minerals Development Sector-Chemical Laboratories (Mission Report Republic of Uganda). Geological Survey and Mines Department, Entebbe.

[25] Fisset, N., Serwanga, C. and Iga, M. (1994) Geophysical Surveys carried out on the Butare Iron Prospect Muko Area, Kabaale District, Southwestern Uganda. Geological Survey and Mines Department, Entebbe.

[26] Parker, M.E.M.E., Byamugisha, S.S. and Turyomurugyendo, G. (1989) Geophysical Surveys on Mineralisation at Kashenyi Ridge, Southwestern Uganda. Geological Survey and Mines Department, Entebbe.

[27] Muwanguzi, J.B.A., Wu, Y., Karasev, V.A., Byaruhanga, K.J. and Pär, G.J. (2013) Investigation of Direct Reduction of Lumps from Natural Hematite Iron Ore. Research and Application of Materials, 1, 73-82. 
https://doi.org/10.12966/ram.09.03.2013

[28] Muwanguzi, J.B.A., Karasev, V.A., Byaruhanga, K.J. and Pär, G.J. (2014) Effect of Different Factors on Low Temperature Degradation of Hematite Iron Ore during Reduction. Metallurgical Research Technology, 111, 57-66.

https://doi.org/10.1051/metal/2014014

[29] Muwanguzi, J.B.A., Alevanau, A. and Byaruhanga, K.J. (2017) Application of Different Models for the Prediction of the Kinetics of Direct Reduction of Natural Iron Ores. Geomaterials, 7, 117-131. https://doi.org/10.4236/gm.2017.74009 